\title{
Editorial: Impacts of Habitat Transformation on Species, Biodiversity and Ecosystems in Asia
}

\author{
Emilio Pagani-Núñez ${ }^{1 *}$, Craig R. A. Barnett ${ }^{2}$, Caroline Dingle ${ }^{3}$, Eben Goodale ${ }^{4}$, \\ Junhua $\mathrm{Hu}^{5}$, Yuanzhi $\mathrm{Li}^{6}$, Yang $\mathrm{Liu}^{6}$, Naicheng $\mathrm{Wu}^{7}$ and $\mathrm{Yi} \mathrm{Zou}^{1}$ \\ ${ }^{1}$ Department of Health and Environmental Sciences, Xi'an Jiaotong-Liverpool University, Suzhou, China, ${ }^{2}$ Department of \\ Zoology, Graduate School of Science, Kyoto University, Kyoto, Japan, ${ }^{3}$ Division for Ecology \& Biodiversity, School of \\ Biological Sciences, The University of Hong Kong, Pokfulam, China, ${ }^{4}$ Guangxi Key Laboratory of Forest Ecology and \\ Conservation, College of Forestry, Guangxi University, Nanning, China, ${ }^{5}$ Chengdu Institute of Biology, Chinese Academy of \\ Sciences, Chengdu, China, ${ }^{6}$ State Key Laboratory of Biocontrol, School of Ecology, Sun Yat-sen University, Guangzhou, \\ China, ${ }^{7}$ Department of Geography and Spatial Information Techniques, Ningbo University, Ningbo, China
}

Keywords: biodiversity loss, conservation, habitat transformation, ecosystem health, urbanization

\section{Editorial on the Research Topic}

Impacts of Habitat Transformation on Species, Biodiversity and Ecosystems in Asia

\section{OPEN ACCESS}

Edited and reviewed by:

Orsolya Valkó,

Hungarian Academy of

Science, Hungary

*Correspondence:

Emilio Pagani-Núñez emilio.pnunez@xjtlu.edu.cn

Specialty section: This article was submitted to Conservation and Restoration

Ecology,

a section of the journa

Frontiers in Ecology and Evolution

Received: 15 September 2021 Accepted: 24 September 2021

Published: 21 October 2021

Citation:

Pagani-Núñez E, Barnett CRA, Dingle C, Goodale E, Hu J, Li Y, LiU Y,

Wu N and Zou Y (2021) Editorial: Impacts of Habitat Transformation on Species, Biodiversity and Ecosystems in Asia. Front. Ecol. Evol. 9:777175. doi: 10.3389/fevo.2021.777175

\section{PRESENT AND FUTURE OF BIODIVERSITY IN ASIA}

Asia is a land of contrasts. This is the largest and most populated continent of the world, it is where urbanization is increasing at the highest rate (Seto et al., 2012). At the same time, it is extremely biodiverse (Myers et al., 2000), so that promoting harmonious human-wildlife coexistence is complex. This complexity is not recent. Ancient civilizations populating this area have left a lasting impact on its nature (Ellis et al., 2021), and recent impacts add to these historical effects. This issue is acknowledged by governments across Asia, who have recently developed numerous initiatives to protect their biodiversity (Ghosh-Harihar et al., 2019; Wu et al., 2019). Yet, despite increasing regional conservation efforts, not all species will make it. For instance, millions-year old species are still being led to extinction (Zhang et al., 2020). In a recent positive development, the United Nations' Convention for Biodiversity (COP-15) will set a 30\% threshold of protected areas of terrestrial land (Zhu et al., 2021). But, to achieve such an ambitious biodiversity conservation goal, urgent action is needed.

This Research Topic aimed to assess the impacts that human-driven habitat transformation has on species, biodiversity, and ecosystems in Asia, and to envision ways in which these impacts can be minimized. Moreover, our intention was to bring together research works from around Asia (and the rest of the world) which address this issue. We gathered papers authored by researchers from 8 countries, i.e., India, China, Singapore, Australia, Pakistan, Brunei, Sri Lanka, and United States. We are convinced that collaboration among Asian nations is an essential condition for any meaningful biodiversity conservation targets to be achieved (Chen et al., 2019; Bawa et al., 2020). We are also convinced that biodiversity conservation should develop interdisciplinary approaches outside the boundaries of traditional academic disciplines, and that it should be science that addresses people's and nature's needs (Kremen and Merenlender, 2018). This collection of 12 papers is our humble contribution to achieve these conservation targets in Asia. 


\section{IMPACTS AND SOLUTIONS}

Due to the broad and ambitious goal of this Research Topic, its papers are heterogeneous in their scopes and aims. In this volume, you will find works focusing on landscape ecology, ecological restoration, human-wildlife conflict, and investigating animal behavior in response to habitat transformation.

Human infrastructure construction is a key driver of biodiversity loss. For instance, hydropower stations are very impactful infrastructures that can profoundly disrupt ecosystem dynamics (Anderson et al., 2015). Here, we are presenting two studies examining the consequences of hydropower station construction for ecosystem dynamics in upstream systems. For instance, using the Lancang River (also known as the Mekong River) Valley (SW China) as a case study, Liu S. et al. showed that forest connectivity decreased after the construction of the station, particularly upstream, in small forest patches and in large patches in the edge of the study area. In another study, Jelil et al. illustrated mammal persistence in upstream riparian forests at Koyna Reservoir (W India) 55 years after the construction of a hydropower station. They show that ungulates were particularly abundant close to the river body, that small body-sized ungulates had higher extinction risk, and that distance to the river was the main factor explaining species detection.

Also from a landscape ecology perspective, Wang et al. quantitatively examined landscape change patterns in the Yancheng National Nature Reserve in the coast of East China to show that newly built artificial landscapes (such as farmland and aquaculture ponds) grew at the expense of natural habitats, and report an overall steep increase in the surface of these humanmade landscapes. Landscape structure plays a fundamental role in shaping biodiversity patterns (Tscharntke et al., 2012). Wu et al. showed that flowering ground cover and the proportion of semi-natural habitats correlated positively with wild bee abundance and diversity, which in turn had a positive impact in apple orchards in the Northern China Plain. Interestingly, in tropical rainforest buffer zones of Sri Lanka, Hanle et al. showed that traditional small-holder tree gardens harbored greater abundance of species of high conservation interest than forest fragments or tea plots. This study is a nice example of how traditional farmlands managed by indigenous peoples can harbor almost as much biodiversity as natural habitats (Bhagwat and Rutte, 2006; Ranganathan et al., 2008).

From landscape to local scales, plant species play a fundamental role in animal conservation and this can be true even for invasive species, which can have in certain instances neutral and positive effects on animal species (Houlahan and Findlay, 2004; Szigeti et al., 2020). Jain et al. showed that tropical butterfly populations of Singapore were highly dependent on non-native host plants. Yet, invasive plants also have wellknown negative effects and can disrupt ecosystem functioning (Simberloff et al., 2013). Two additional studies in this collection focused on plant ecology. Chen et al. tested several hypotheses that could explain patterns of exotic plant invasions in natural reserves of China and found that human activities are the main facilitators of these invasion processes. Hayyat et al. conducted a study in Pakistan showing the potential for plant restoration in quarry sites using limestone quarry waste to promote the growth of two woody Angiosperm species.

Another key aspect of wildlife conservation in our region is to investigate ways to promote dispersal of large mammals and ameliorate conflicts with humans (Goswami and Vasudev, 2017). Liu X. et al. investigated potential dispersal routes of giant pandas in a key distribution area in China and provided recommendations to favor this natural process. Tripathy et al. performed a comprehensive spatial analysis of human-elephant conflict in Keonjhar (E India), an area where 345 people have been killed by elephants between 2001 and 2018, to ensure that mitigation efforts are directed to priority areas.

Finally, Sung et al. investigated population trends of wintering waterbirds in the Deep Bay area (S China), a wetland of international importance over a 20 -year span, showing that larger species strongly dependent on the Yellow Sea and breeding in Southern Siberia experienced steeper declines, while Liang et al. provided insights on individual niche variation across habitat transformation gradients of birds and frogs. This last study highlights how important is to better understand biodiversity responses to habitat transformation, such as how species forage and select territories in human dominated habitats.

\section{COP-15: BUILDING AN ECOLOGICAL CIVILIZATION}

The years 2021 and 2022 will be crucial for biodiversity conservation across countries in the world, as the United Nations' Convention for Biodiversity (COP-15) on-site meeting is scheduled to take place in October, 2021 in Kunming, Yunnan (SW China). As an area where our lack of knowledge of the effects of human-driven habitat transformation is laid bare, Asia has large areas of intense human concentration and has experienced rapid changes. Therefore, we believe this collection of works serves as an example of how landscape ecology and biodiversity conservation have progressed in Asia in recent decades. This is crucial as Asian countries continue to grow, both economically and population wise, which has the potential to impact its extremely diverse ecosystems. From a broader perspective, it seems clear that the events taking place in this continent will strongly determine the future of our shared Earth-for both people and biodiversity.

\section{AUTHOR CONTRIBUTIONS}

EP-N wrote a first draft. All authors contributed to the article and approved the submitted version.

\section{ACKNOWLEDGMENTS}

We are very grateful to all our colleagues who submitted, reviewed and edited manuscripts for this Research Topic. 


\section{REFERENCES}

Anderson, D., Moggridge, H., Warren, P., and Shucksmith, J. (2015). The impacts of 'run-of-river' hydropower on the physical and ecological condition of rivers: physical and ecological impacts of ROR hydropower. Water Environ. J. 29, 268-276. doi: 10.1111/wej.12101

Bawa, K. S., Goodale, E., Mtemi, W., Chen, Y.-F., Barthakur, R., Goodale, U. M., et al. (2020). China and India: toward a sustainable world. Science 369:515. doi: $10.1126 /$ science.abd 4723

Bhagwat, S. A., and Rutte, C. (2006). Sacred groves: potential for biodiversity management. Front. Ecol. Environ. 4, 519-524. doi: 10.1890/1540-9295(2006)4519:SGPFBM2.0.CO;2

Chen, C., Park, T., Wang, X., Piao, S., Xu, B., Chaturvedi, R. K., et al. (2019). China and India lead in greening of the world through land-use management. Nat. Sustain. 2, 122-129. doi: 10.1038/s41893-019-0220-7

Ellis, E. C., Gauthier, N., Goldewijk, K. K., Bird, R. B., Boivin, N., Díaz, S., et al. (2021). People have shaped most of terrestrial nature for at least 12,000 years. Proc. Natl. Acad. Sci. 118:e2023483118. doi: 10.1073/pnas.2023483118

Ghosh-Harihar, M., An, R., Athreya, R., Borthakur, U., Chanchani, P., Chetry, D., et al. (2019). Protected areas and biodiversity conservation in India. Biol. Conserv. 237, 114-124. doi: 10.1016/j.biocon.2019.06.024

Goswami, V. R., and Vasudev, D. (2017). Triage of conservation needs: the juxtaposition of conflict mitigation and connectivity considerations in heterogeneous, human-dominated landscapes. Front. Ecol. Evol. 4:144. doi: $10.3389 /$ fevo.2016.00144

Houlahan, J. E., and Findlay, C. S. (2004). Effect of invasive plant species on temperate wetland plant diversity. Conserv. Biol. 18, 1132-1138. doi: 10.1111/j.1523-1739.2004.00391.x

Kremen, C., and Merenlender, A. M. (2018). Landscapes that work for biodiversity and people. Science 362:eaau6020. doi: 10.1126/science.aau6020

Myers, N., Mittermeier, R. A., Mittermeier, C. G., da Fonseca, G. A. B., and Kent, J. (2000). Biodiversity hotspots for conservation priorities. Nature 403, 853-858. doi: $10.1038 / 35002501$

Ranganathan, J., Daniels, R. J. R., Chandran, M. D. S., Ehrlich, P. R., and Daily, G. C. (2008). Sustaining biodiversity in ancient tropical countryside. Proc. Natl. Acad. Sci. 105, 17852-17854. doi: 10.1073/pnas.0808874105

Seto, K. C., Guneralp, B., and Hutyra, L. R. (2012). Global forecasts of urban expansion to 2030 and direct impacts on biodiversity and carbon pools. Proc. Natl. Acad. Sci. 109, 16083-16088. doi: 10.1073/pnas.1211658109
Simberloff, D., Martin, J.-L., Genovesi, P., Maris, V., Wardle, D. A., Aronson, J., et al. (2013). Impacts of biological invasions: what's what and the way forward. Trends Ecol. Evol. 28, 58-66. doi: 10.1016/j.tree.2012.07.013

Szigeti, V., Fenesi, A., Soltész, Z., Berki, B., and Kovács-Hostyánszki, A. (2020). Neutral effect of an invasive plant species with specialized flower structure on native pollinator communities. Biol. Invasions 22, 3017-3030. doi: 10.1007/s10530-020-02305-6

Tscharntke, T., Tylianakis, J. M., Rand, T. A., Didham, R. K., Fahrig, L., Batáry, P., et al. (2012). Landscape moderation of biodiversity patterns and processes eight hypotheses. Biol. Rev. 87, 661-685. doi: 10.1111/j.1469-185X.2011.00216.x

Wu, R., Possingham, H. P., Yu, G., Jin, T., Wang, J., Yang, F., et al. (2019). Strengthening China's national biodiversity strategy to attain an ecological civilization. Conserv. Lett. 12:e12660. doi: 10.1111/conl.12660

Zhang, H., Jari,ć, I., Roberts, D. L., He, Y., Du, H., Wu, J., et al. (2020). Extinction of one of the world's largest freshwater fishes: lessons for conserving the endangered Yangtze fauna. Sci. Total Environ. 710:136242. doi: 10.1016/j.scitotenv.2019.136242

Zhu, L., Hughes, A. C., Zhao, X.-Q., Zhou, L.-J., Ma, K.-P., Shen, X.-L., et al. (2021). Regional scalable priorities for national biodiversity and carbon conservation planning in Asia. Sci. Adv. 7:eabe4261. doi: 10.1126/sciadv.abe4261

Conflict of Interest: The authors declare that the research was conducted in the absence of any commercial or financial relationships that could be construed as a potential conflict of interest.

Publisher's Note: All claims expressed in this article are solely those of the authors and do not necessarily represent those of their affiliated organizations, or those of the publisher, the editors and the reviewers. Any product that may be evaluated in this article, or claim that may be made by its manufacturer, is not guaranteed or endorsed by the publisher.

Copyright (๐ 2021 Pagani-Núñez, Barnett, Dingle, Goodale, Hu, Li, Liu, Wu and Zou. This is an open-access article distributed under the terms of the Creative Commons Attribution License (CC BY). The use, distribution or reproduction in other forums is permitted, provided the original author(s) and the copyright owner(s) are credited and that the original publication in this journal is cited, in accordance with accepted academic practice. No use, distribution or reproduction is permitted which does not comply with these terms. 